\title{
Constructing Gender Identity in Young Children
}

\author{
Nelis Nazziatus Sadiah Qosyasih ${ }^{1, *}$, Vina Adriany ${ }^{2}$ \\ ${ }^{1,2}$ Department of Early Childhood Education, School of Postgraduate, Universitas Pendidikan Indonesia \\ *Corresponding author. Email: nelisnsa2@upi.edu
}

\begin{abstract}
This paper aims to discuss the role of parents in constructing gender identity in early childhood. Based on the existing literature, the writers argue that parents still tend to treat boys and girls differently, reflecting a patriarchal culture in the society. This paper uses a post structuralist feminist theory. From the literature review, it is found that to overcome gender inequality it is important for parents to understand gender equities. The main result of this literature review is the importance of understanding, voicing and implementing gender equality values in early childhood in the community, starting from parents at home to minimize social inequality.
\end{abstract}

Keywords: Construction, gender, early childhood, feminist post structuralist.

\section{INTRODUCTION}

Parents play important roles in children development [1], [2] including in the development of children's gender understanding [1] through actions and role models.

Gender itself is a social construct [3], [4] and varies across culture [5]. This means gender is a historical a social product that has been ingrained in society to that extent it is seen as something natural. According to Butler [3], [4] gender construction is reiterated so that it becomes a taken for granted concept, despite the fact it is a social construction that is open to be deconstructed [6].

Gender as a social construction will determine how women and men think, act and feel in a cultural context [7]. As a construction, gender is often understood as a set of rules or behaviour prohibitions for individuals who have a specific gender. This varies from culture to culture [8], [9], [10], [11].

This paper adopts literature and previous research both on global [12], [13], [14], [15] and Indonesia scales [16], [17] on gender construction in young children. The results of this study are expected to assist parents and teachers in understanding the importance of gender flexible roles in young children.

\section{LITERATURE REVIEW}

This paper uses a post-structuralist feminist perspective to analyse gender construction in children which refers to Foucault's theory on power, particularly on how power produces differences between girls and boys. Post-structuralist feminists are philosophies, theories and methodologies to determine power relations through discourse analysis [18]. This theory has been used in research on gender, power and play in children [17].

As mentioned before, post-structuralist theories are informed by Foucault 's approach to power and discourse. This allows us to break many of these taken for granted assumption about gender in ways that we can challenge the dominant gender order. Children get gender identities from various groups, one of them from their parents [19], teachers and people around them contribute greatly to constructing children's gender [20].

In post-structuralism, gender is defined as a social construction in shaping femininity and masculinity [21]. Gender construction is partially shaped by language, along with physical and material resources such as clothes and attributes used that are affiliated to a certain gender [21]. Central to post-structuralist theories is an idea that gender order can be challenged and negotiated.

According to Hurst \& Smith [22] post-structuralist feminism is a theoretical lens that specifically discusses how children's gender is formed. In post structuralist feminists, gender is a complex and dynamic collection of ideas, actions and feelings as a boy or girl in a different place, culture and time [23]. In the post-structuralist perspective, both children and adults play an active role in re-constructing gender discourses.

\section{METHOD}

This paper examines ranges of literature review to unpack how previous research understand the issues of gender in the early years [24]. We adopt post- 
structuralist feminist concepts that discuss language and power to understand gender construction in children carried out by parents.

\section{RESULT AND DISCUSSION}

\subsection{Language}

Post-structuralism interprets that all meaning and knowledge is formed through language [12] and language is the key to how we create meaning as socially constructed individuals. If meaning is created through language, it is impermanent or essential. As a place of social and political struggle, language is a place where social meanings and identities about femininity and masculinity are shaped and reformed. It is also a space where this social meaning is open to redefining, challenging, and reinterpreting [25]. This understanding of the construction of knowledge goes away from the belief that children are only born in their gender or simply learn their gender and sexuality by copying adults.

Through conversation and interaction with each other, children and adults negotiate what it means to be women and men. Certain talks and actions will reinforce gender stereotypes. Words such as beauty promotes a version of femininity, while words like handsome perpetuates a type of masculinity.

\subsection{Power}

Post-structuralist feminists refer to Foucault's theory of power, a philosopher, psychologist and historian [26]. From this perspective, power is seen as a process operating in our social world, not as something that is owned by individuals. Power operates in all relationships and is expressed through discourse. Therefore, Foucault argues for the understanding of power as something that circulates and at the same time operates to produce certain types of subjects. According to Foucault and the feminist poststructuralist who use his work, "the individual is the vehicle of power. From this perspective, it becomes important to understand how power strategies and techniques work, not just who has or doesn't have power. How power generates gender identities as women and men is relevant to understanding gender [12].

Foucault argues that power and knowledge are interrelated and greatly influence each other. Power relations exist in the field of knowledge, or "regime of truth", which produce and carry out certain forms of power relations [12]. By examining power as a relation and in its local form, we can understand the ways in which gendered social orders are structured and regulated. In the case of young children, it is through power-relations between adults and children, young children will be engaged in the continuous process of constructing and negotiating their gender.

\section{CONCLUSION}

The formation of gender identity in children cannot be separated from the influence of adults. In Indonesia, parents and teachers still use hold on to traditional gender discourses in educating their children [17]. Feminists' post-structuralist view that gender is the result of social construction [22], so everything is not final. Elements that can influence gender identity are language and power, both of which view that children's gender identity is fluid and flexible.

As a foundation for children's education, it is important for adults to understand and implement the values of gender equality in children in order to ensure that children are respected as who they are.

\section{REFERENCES}

[1] Santrock JW. Masa perkembangan anak. Jakarta: Salemba Humanika; 2011.

[2] Santrock JW. Educational psychology. $6^{\text {th }}$ Edition. New York: McGraw Hill Education; 2016.

[3] Butler J. Performative acts and gender constitution: An essay in phenomenology and feminist theory. Theatre Journal. 1988;40(4):519-531.

[4] Butler J. Gender trouble, feminist theory, and psychoanalytic discourse. In: Linda JN, editor. Feminism/Postmodernism. New York: Routledge; 1990. p. 324-340

[5] Jackson A. The British empire and the second world war. London: A\&C Black; 2006.

[6] Warin J, Adriany V. Gender flexible pedagogy in early childhood education. Journal of Gender Studies. 2017;26(4):375-86. https://doi.org/10.1080 /09589236.2015.1105738.

[7] Tampubolon GN. Identitas dan peran gender pada anak usia 3-7 tahun dalam keluarga komuter. Jurnal CARE (Children Advisory Research and Education). 2018;6(1):1-9. Available from: http://e-journal .unipma.ac.id/index.php/JPAUD.

[8] Money J, Ehrhardt AA. Man and woman, boy and girl: Differentiation and dimorphism of gender identity from conception to maturity. London: Johns Hopkins U Press; 1972.

[9] Whitehead MI, Townsend PT, Pryse-Davies J, Ryder TA, King RJB. Effects of estrogens and progestins on the biochemistry and morphology of the postmenopausal endometrium. New England Journal of Medicine. 1981;305(27):1599-605.

[10] Nicholson L. Interpreting gender. Signs: Journal of Women in Culture and Society. 1994;20(1):79-105.

[11]Blaise M. "What a girl wants, what a girl needs": Responding to sex, gender, and sexuality in the early childhood classroom. Journal of Research in 
Childhood Education. 2009;23(4):450-60. https:// doi.org/10.1080/02568540909594673.

[12]Blaise M. Charting new territories: Re-assembling childhood sexuality in the early year classroom. Gender and Education. 2013;25(7):80117.

[13] Şalgam D. Gender and sexual identity construction in early childhood education: The case of a private kindergarten in Ankara [Master Thesis, Middle East Technical University]. Ankara: METU; 2014.

[14] MacNaughton G. Constructing gender in early-years education. London: Sage Publications; 2006.

[15] Gunawan MT. Analisis konstruksi gender melalui media pembelajaran di pendidikan anak usia dini: Penelitian etnografi terfokus di Taman Kanak-kanak di Kota Bandung [Doctoral Dissertation, Universitas Pendidikan Indonesia]. Bandung: UPI; 2018.

[16] Ramdaeni S, Adriany V, Yulindrasari H. Gender, power and play in early childhood education. In Proceeding of the $1^{\text {st }}$ International Conference on Educational Sciences (ICES 2017). 2018. pp.109-14. Available from: https://doi.org/10.5220/000704600 6580663.

[17] Aston M. Teaching feminist poststructuralism: Founding scholars still relevant today. Creative Education. 2016;7(15):2251-67. https://doi.org/10. 4236/ce.2016.715220.

[18] Messner MA. Barbie girls versus sea monsters: Children constructing gender. Gender \& Society. 2002;14(6):765-84. Available from: https://doi.org/ 10.1177/089124300014006004.

[19] Adriany V, Warin J. Preschool teachers' approaches to care and gender differences within a child-centred pedagogy: findings from an Indonesian kindergarten. International Journal of Early Years Education. 2014;22(3):315-28. Available from: https://doi.org/10.1080/09669760.2014.951601.

[20] Änggård E. Children's gendered and non-gendered play in natural spaces. Children Youth and Environments. 2011;21(2):5-33.

[21]Hurst B, Smith K. Feminist post structuralist framings of professional identities. Encyclopedia of Teacher Education; 2020:1-5. Available from: https://doi.org/10.1007/978-981-13-1179-6_384-1.

[22] MacNaughton G, Davis K. Beyond 'Othering': Rethinking approaches to teaching young AngloAustralian children about indigenous Australians. Contemporary Issues in Early Childhood. 2001;2(1):83-93.

[23] Gay LR, Mills GE, Airasian PW. Educational research: Competencies for analysis and application. Columbus: Merrill; 1976.
[24] Weedon C. Post-war women's writing in German: Feminist critical approaches. Oxford: Berghahn Books; 1997.

[25] Sergiu BM. Foucault's view on power relations. Cogito: Multidisciplinary Research Journal. 2010;(2):55-61. 